\title{
Applications of Social Media in the Tourism Industry: A Review
}

\author{
Md. Tariqul Islam ${ }^{1 *}$ \\ ${ }^{1}$ School of Hotel Management and Tourism, Lovely Professional University, India \\ * Corresponding author: tariqul.tonmoy812@gmail.com
}

Article History

Received 2021-01-18

Revised 2021-01-24

Accepted 2021-01-25

Published 2021-01-28

\section{Keywords}

Social Media

Tourism

Consumer

Supplier

\section{How to cite?}

Islam, M. T. (2021). Applications of

Social Media in the Tourism Industry: $A$

Review. SEISENSE Journal of

Management, 4(1), 59-68. doi:

$10.33215 /$ sjom.v4i1.556

\begin{abstract}
Purpose- This study aims to review and analyze the articles related to social media applications and their impact on the tourism industry.
\end{abstract}

Methodology- For conducting this study, three leading databases named Google Scholar, Science Direct, and EBSCO Host were used for data collection purposes, and the research was conducted in three phases. Selecting the database for collecting data was the first phase, which was carried out during the period between November 2020 to December 2020. In the second phase, screening of the collected data was done, and in the final stage, 46 articles were selected to conduct this study.

Discussion- Over the last decade, the rapid advancements in information and communication technology (ICTs) have had reflective impacts on the global tourism sector. Both researchers and professionals have acknowledged that social media applications have a significant impact on both suppliers and consumers of the tourism industry.

Findings- Based on the reviewed articles from the perspectives of the tourism consumers as well as the tourism suppliers, this study has found that consumers use social media in pre-during-post travel for searching different information and suppliers generally use social media for promotion, communication, management, research purposes. 


\section{Introduction}

A great variety of virtual tools have been created by the invention of the internet and simultaneously, it has also contributed to the rise of social networks that have become prominent today. Different terms and virtual discoveries were created with the advent of the internet. In the $21^{\text {st }}$ century, social networking services began with the chat names to impart chat communication in the forum (Kayumovich \& Kamalovna, 2019). Social media is noticed in social and economic life in the modern world as it is one of the most vital online networking resources. Social media is the medium of interaction between individuals in which they build, share, and exchange knowledge and information in digital environments (Kaplan \& Haenlein, 2010). In their study, Javed et al., (2020) mentioned that Cohen provided a meaningful description of social media by reviewing thirty separate social media meanings and explaining the essential characteristics of it. These characteristics are (1) social media requires internet-based software, platforms, and resources and therefore relies only on information and communication technology for technological operationalization; (2) social media denotes the channels of communication that facilitate the participants as well as the public to create and share content and collaborate, directing to omnipresent transforms; and (3) social media link its users within a virtual world which has an impact on people's actions in real life (Zeng \& Gerritsen, 2014). Social media can be considered as a community of fully online-based services formed through the conceptual and technical substructure of Web 2.0. Moreover, the user-generated content is allowed to be shaped and produced (Zeng \& Gerritsen, 2014). Several types of social media are listed below:

- Blogs are defined as formal website-published articles, journals, or newsletters. It is also considered the initial formation of web version 2 that assists the users while uploading online format data entries, pictures, videos, links, or other digital media. Since it allows its user to maintain the communication between them by posting a statement or comment, which is the central essence of social networking, this type of Web Version 2 may well be called social media. Content created by users and reciprocal or dual-track communication among the users is accommodated (Kennedy, et al., 2007; Hidayat \& Are, 2018).

- Social Networking refers to a private website that operates on a broader network from where the users are stimulated to communicate between themselves to build a group (Kennedy, et al., 2007). Moreover, the social networking essential and notable characteristics include the use of accounts, personal sites, images, and messages to strengthen the user-to-user connection (Goeldner \& Ritchie, 2011; Hidayat \& Are, 2018).

- Content communities whose aim is to form social networking allow users to exchange media content between themselves (Goeldner \& Ritchie, 2011; Hidayat \& Are, 2018).

The analytical application of social media in the hospitality and tourism industry is considered as the most preferred area due to its incredible progress and evolution (Xiang, Du, Ma, \& Fan, 2017). Social media manipulations converted into a significant social sensation and an intercontinental trend in the industrial sector (Hays, Page, \& Buhalis, 2013). Consumer behavior in tourism has always been guided through the growth of information and communication technology (Buhali \& Law, 2008) and, in particular, web 2.0, which has vitally altered the way users organize and purchase travel-related commodities (Fotis, Buhalis, \& Rossides, 2012). The consumers' behavior does not sustain for a long time, and it keeps on changing over time. The advancement and the social media growth have a powerful stimulus on changing consumers' consumption, such as evaluating, selecting, and purchasing goods and services, which keeps the marketer in anxiety. It is challenging to set new strategies, policies, and tactics with consumer behavior changes (Leung, Sun, \& Bai, 2017). Gretzel et al., (2008) anticipated that the usage of social media on travel is monumental. In 2008, 82 percent of online consumers of the USA were found to have reviewed online reviews, blogs, and other online input for their 
buying decisions related to travel. The advancement of technology, mainly the inauguration of Web Version 2, which began in this modern age, contributed to the Social media formation, making it very important to market a tourist destination (Chan \& Guillet, 2011; Goeldner \& Ritchie, 2011).

Additionally, the prominence of social media is seen as the source of research data in numerous area such as the mechanism of customer decision-making, e-word of mouth, and travel recommendations have grown (Hudson \& Thal, 2013; Ye, Law, Gu, \& Chen, 2011; Kurashima, Iwata, Irie, \& Fujimura, 2010; Cheng \& Edwards, 2015). The World Tourism Organization recognizes the critical role of social networking in tourism. Visitors and business people use smartphones and tablets to provide reviews on places to go or wherever they are. The World Travel Monitor confirms that 40 percent of foreign tourists use smartphones to travel. They have access to the Internet from their smartphones; 40 percent for travel information, about 26 percent for travelers, 34 percent for hotel reservations and other travel-related services (Kayumovich \& Kamalovna, 2019). With smartphones, travel, ideas, and feedback on Facebook, Twitter, or Flickr, three-thirds of international travelers access social networks. Social media can be used by all sectors as an essential tool for marketing, as the growth rate of social media is substantial. Since the industry has extensive trust primarily on destination credibility, customer sentiment, distribution of information, and positive word-of-mouth ads, the tourism industry is geared up to benefit from different platforms of social media (Gohil, 2015). The purpose of conducting this study is to review and analyze the articles related to the applications of social media and its influence on the tourism industry.

\section{Methodology}

Selection of the database for collecting data was the first stage of this study; from November 2020 to December 2020, a data collection process has been conducted. The three most popular and largest databases have been used for data collection purposes named Google Scholar, Science Direct, and EBSCO Host. According to the suggestions of Leung et al., (2013), some keywords were used for identifying the related articles which have been published by different journals and available in online and those keywords are social media, technology, internet, tourism, consumer behavior, tourist behavior, holiday planning, promotion, marketing tools, distribution channel, communication, hotel, restaurant, hospitality. Articles were retrieved from different journals of the Tourism and hospitality domain due to the less availability of related published articles. After the data collection and doing a few rounds of screening, 46 articles were found relevant to that study published between 2008 to 2020 in the third stage. For checking the article's relevance with the study, the abstract and keywords of the article were analyzed. If the abstract and the keywords of the article were found relevant with the theme of the study then that article was selected for reviewing thoroughly where the objectives, methodology, and the findings of that article were analyzed for collecting the data and those data have been used for conducting the study. Finally, the number of articles were calculated where it was seen that the maximum number of articles were picked from the year of 2011 and 2019 (Figure: 1).

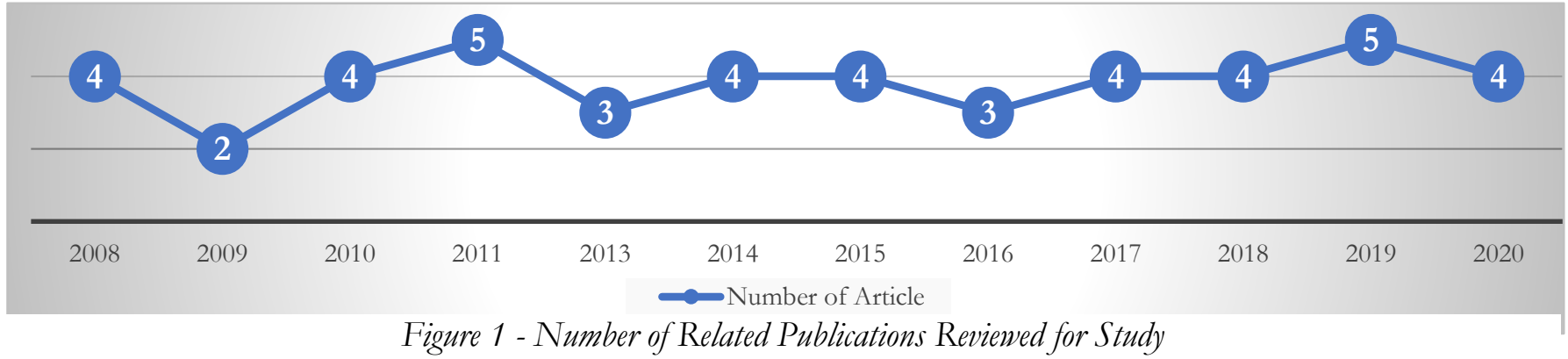




\section{Applications of Social Media in Tourism}

As an emerging subject in the tourism industry, social media's position has been illustrated and researched progressively. Travel 2.0 is a new term that has been developed as a fresh concept which indicates the progress of social media's significance in travel and recent buyers in the travel industry (Chu, Deng, \& Cheng, 2020; Baker \& KaWon, 2019; Lo \& Yao, 2019; Chang, Ku, \& Chen, 2019; Mariani, Styven, \& Ayeh, 2019). Social media plays an increasingly important role in many aspects of tourism, exclusively while searching information, making the decision and promoting tourism, focusing on the best applications to engage with customers through the platforms of social media (Sahoo \& B.G, 2017). Apart from the influences on tourist consumption behavior, social media's evolution has influenced the research area related to tourism and hospitality. For the last twenty years, the researchers have acknowledged that social media has made it essential for tourists to decide and plan their trip (Zarezadeh, Rastegar, \& Gretzel, 2018; Cholprasertsuk, Lawanwisut, \& Thongrin, 2020). An excellent technique has been demonstrated to exploit social media to sell tourism products. Many countries and states view social media as a primary tool for supporting their tourism industries. An organization's social media marketing strategy describes how the organization utilizes social media resources (ex; Facebook, Twitter, and YouTube) to fulfill the organization's marketing target. The social media strategy helps to implement and promote eminent approaches offers insights on markets and consumers that are used to build and change the company's business strategy. The current approach used by the company's' case study on the application of social media marketing specifies that the business plan is not entirely implemented. The company needs further decisions on optimizing the marketing resources available to win more customers based on the amendment strategy they are going towards in terms of using social media marketing to market their company (Gohil, 2015). Tussyadiah \& Fesenmaier (2009), recommended that user Generated Content (UGC) has increasingly shaped destination visibility on social media and subsequent destination selection decisions. Indeed, UGC can provide travel consumers with incomparable, unparalleled, latest, and differentiated formats of information (Leung, Law, Hoof, \& Buhalis, 2013).

\section{Applications of Social Media from the Consumers' Perspective}

The latest Google research has shown that before going on a holiday, the internet is used as a planning resource by eighty-four percent of leisure travelers (Leung, Law, Hoof, \& Buhalis, 2013). Xiang \& Gretzel (2010) mentioned that the search results of Social networking are accounted for not less than one-tenth when analyzing the possibility that online travelers prefer social media material more while processing a web search. With the popularity of websites containing traveler-generated content, several scholars acknowledged the primary influence of social media in the pre-trip research process, also speculating that the primary motive of the application of the social media and the user-generated content (UGC) by travelers was to obtain travel-related information (Tussyadiah, Park, \& Fesenmaier, 2011; Cox, Burgess, Sellitto, \& Buultjens, 2009; Lo, Mckercher, Lo, Cheung, \& Law, 2011; Huang, Basu, \& Hsu, 2010). Xiang \& Gretze (2010) stated that many of these social media platforms help customer share their observations, views, personal experiences, and thoughts related to travel which later on serve as information for the prospective travelers. A new study on American tourists revealed that social media inclines to be the leading hub of information when tourists make travel plans. This study also showed that searching and preparing for the tourist's potential tourism experience, their dependence on information technology increased highly (Xiang, Wang, O’Leary, \& Fesenmaier, 2014). Check-in features in social media have created a new horizon in the tourism industry, Check-in helps the tourist to share their experience of a specific place, area, destination by tagging the exact location through the usage of GPS, and that allowed the potential consumers to enhance their tourism-related knowledge through the precise information regarding any sites which helps the marketers to build a relationship with the consumers that a sustain for a long term (Vu, Li, Law, \& Zhang, 2017; Jin, Long, Zhang, Lin, \& Joshi, 2016; Chen, et al., 2016; Roque \& Raposo, 2016). Tourists have realized that social media is considered as an essential instrument for 
them while choosing the destination for traveling, having food and beverages, and shopping compared to other tools. Simultaneously, users are becoming much more familiar with the Internet's encryption and personalized services (Wei, 2015). Moro \& Rita (2018) stated that social media's application by any organization influences consumer perception towards a brand's products and services, such as customer satisfaction, outlook towards that brand, and purchase intention. For collecting information regarding travel planning, WOM is known as the significant exterior hub of details due to the more substantial trustworthiness of WOM between all other available sources. While purchasing a product, consumers usually prefer to create their perception based on the review of fellow consumers or their friends (Leung, Law, Hoof, \& Buhalis, 2013).

\section{Applications of Social Media from the Suppliers' Perspective}

Social media has played a prominent role in being future promotion tools and can impact the buying decision of the consumer. Social networking can draw future travelers by providing or even manipulating data around the destination. To quickly share information, they were given the opportunities of significant disclosure to a dynamic and collective form by social media as well as it has a substantial impact on different types of products, brands, services, locations, cultures, economic, political, and social because now people can talk about their views on the correlated issue (Hidayat \& Are, 2018). The social networking sites have carried out the notable change in disseminating and exchanging information as a kind of information technology. They have gradually evolved into a direct sales channel that includes tourism delivery, bring changes to its work (Lewis \& Bridger, 2001). The business of tourist destination has been modernized due to the touches of the internet as it can be used as the channel of distribution and the sources of information and the shared information, review, recommendation of the visitors helps to attract and reach the potential consumers from different geographical location (Királ'ová \& Pavlíčeka, 2015). The acceptance of smartphones makes the visitors able to browse social media conveniently and places through the Internet. It has a significant effect on searching for knowledge and behavior planning (Dan, Xiang, \& Fesenmaier, 2014). Thus, it is clear that the Internet has conceptualized how tourists find and buy the products and services of tourism, changing the delivery of tourism services and products, making the combination of the design of tourism services and products more tailored. Social media has steadily rebuilt the business process in all businesses in the distribution networks for the participants of the distribution channel with the provisions of redefining their key competitiveness (Wei, 2015). Sharda \& Ponnada (2008) mentioned that travel organizations might generate revenue by linking e-commerce websites and organizations' booking platforms with travel blogs. Noone et al., (2011) stated that the customers are being encouraged to book directly from the service providers' websites or organization's given link, which is attached on social media, rather than book it through a third party. They also suggested that revenue managers can use UGC on social media to develop effective strategies. Leung et al., (2013) stated that the suppliers could gather knowledge and information regarding the consumers' likes and dislikes by reviewing the comments posted by consumers on different online communities like TripAdvisor to determine what to minimize what to maximize. With one business model after another, social media-based entities have altered standard distribution strategies and steadily shown that product selectivity is less critical than trading convenience. Hidayat \& Are (2018) stated that four important pillars influence the contact success rate across social media, which are:

- Set up efficient contact with the client.

- Collaborating with the client.

- Attempting to educate the client.

- Ensuring fun for the customers.

To promote the goods and services efficiently and effectively, these foundations were established. It is essential to develop a good relationship with the client to ensure its efficacy, being trustworthy and consistent with the material that has been released since the usual word for advertising is unable to sustain for long-term projects. 
Depending on the topics under research and the form of contact, social media tends to affect communication either positively or negatively. To have a competitive product/service experience, social media requires the convergence of all marketing practices and uses convincing ads for marketers to understand. This new communication medium helps consumer relationships in the best way where electronic Word of Mouth (eWOM) is critical. Due to product or service change, the e-WOM may increase tourist satisfaction (Živković, Gajic, \& Brdar, 2014). At the same time, during the journey, e-WOM can address issues and questions. It can help while finding out about what visitors imagine and say about their demands and experience. However, the essential advantage is monitoring the organization's reputation/image, even reviewing current strategic strategies (Litvin, Goldsmith, \& Pan, 2008). The usage of social media has two implications; first, by establishing a good and productive customer relationship that increases the company's loyalty. It can be used as a powerful tool for gathering feedback from the customer that can be used to attract new customers and retain existing customers (Leung, Law, Hoof, \& Buhalis, 2013). Secondly, if not used correctly, the decline in customers' confidence and the brand's market value and managing this essential source of knowledge about strategic social media is the key that decides the consequence of the company's adoption of social media and revenues. UGC is increasingly being regarded on social media as a digital source of expertise for analyzing external and internal environmental studies. UGC's social media analysis could provide a clear and compelling concept of the consumers' characteristics by using particular social media apps. The data could be used for directing the expansion of the targeted ads and advertising information for separate social media apps (Noone, McGuire, \& Rohlfs, 2011). The tourism industry suppliers can maintain a strong relationship with the consumers by making proper effective strategy by observing the consumers' participation interaction, behavior, and thought from social media (John, Larke, \& Kilgour, 2018; Winduwati \& Putri, 2020) .

\section{Findings}

Social media has been a convenient option to reach and connect at an unprecedented level with the masses. Individuals, corporations, and public figures also use social media as an advertisement platform. In the present decade, it is almost difficult to think about a future without social networks. It influences individuals' daily lives and impacts different industries, especially the tourism and hospitality industry, such as in promotion, market management, and analysis functions, due to their continued global growth. Social media provides tourism suppliers with the opportunity to be highly exposed to a diverse and integrated type to exchange information quickly. Nowadays people would like to share their opinion on the crucial topic. For the distribution channel players, social media has continuously rebuilt all companies' sales processes in the distribution networks to redefine their main competition. Social media are used for creating a healthy and positive customer relationship that improves the company's satisfaction; it could be an effective method for gaining customer input that is used to achieve potential consumers and maintain current customers. Social media is also used by the management in researching customers' characteristics. Social media has been accepted as an ideal route to maintain communication with the masses at a rocketing speed because of that the individuals as well as the organizations are using social media to reach their potential consumers. Social media helps the organizations to observe the demand for their product, their users' attitudes, and customer satisfaction levels which help the organizations to set different innovative and effective strategies and policies to meet the customer's needs apart from that social media can be used as a useful promotional tool as the potential consumers become more influenced by the social media's activities of a particular brand or organization. As a popular communication platform, an effective social media network will continue to disseminate information to those who need access.

Social media assist the tourist in their travel planning, and it has a significant influence on pre-during-post traveling. Tourists have now revealed that in comparison to other tools, social media is the essential element for them to make decisions on choosing the destination, catering, and shopping. Nowadays, social media has added another feature called check-in, which works with the help of GPS. Tourist can share their experience 
regarding any specific tourist destination by tagging that place, which helps the potential tourist as they like to gather information before making travel plans. Many social media sites allow tourists to upload and express their travel-related comments, perspectives, and specific observations, which further act as feedback for others. At present, a world without social networks is almost hard to view. Social media has an impact on people's everyday lives and various businesses; particularly tourism and hospitality business, due to its continued global development, in factors such as promotional factors, business management factors, and research functions.

\section{Conclusion}

The tourism and hospitality industry has been transformed a lot due to the evolution of the internet and its significant addition is social media, which has created a new horizon in the tourism industry. It has been recognized as a preferred path to connect and reach the masses at an exponential pace. Since social media can work as an advertising tool, individuals and the industry have used it to reach their potential consumers. A powerful social networking site can disseminate knowledge to those who necessitate access as a powerful tool for outreach. It is vibrant as the customers are informed of various useful information regarding the offers and the newly arrived services. Nowadays, a world without social networks is almost hard to imagine. Not only it has an impact on people's everyday lives, but also it affects various businesses, particularly tourism and hospitality, due to their continuous global development, in factors such as the promotion of different products and services, business management like setting strategies and tactics, and research functions to identify customer satisfaction, customers' involvement and attitude towards the brands. Since social media shares messages quickly and people follow them, it can be said that it is imminent for the tourism and hospitality industry to pay attention to any technological innovations that occur. By reviewing 46 articles regarding the application of social media in the tourism and hospitality industry, this study contributes by providing a clear overview about what researchers have found regarding the applications of social media in the tourism and hospitality industry from the period of 2008-2020 and this study will help the industry personnel and the academician to understand how social media is using by the consumers and the suppliers of the tourism and hospitality industry. Future research can be conducted on analyzing social media advancement as Jang \& Park (2011) suggested that for getting a comprehensible concept about social media applications in the tourism and hospitality industry, future research should be conducted to implement the content analysis in a quantitative approach for observing the methodological, topical, and authorship trends.

Funding: This research received no external funding.

Conflicts of Interest: The author declares no conflict of interest.

\section{References}

Baker, M. A., \& KaWon, K. (2019). Value destruction in exaggerated online reviews: the effects of emotion, language, and trustworthiness. International Journal of Contemporary Hospitality Management, 31(4), 1956-1976.

Buhali, D., \& Law, R. (2008). Progress in Information Technology and Tourism Management: 20 Years on and 10 Years After the Internet-The State of e'Tourism Research. Tourism Management, 29(4), 609623. doi:10.1016/j.tourman.2008.01.005

Chan, N. L., \& Guillet, B. D. (2011). Investigation of Social Media Marketing: How Does the Hotel Industry in Hong Kong Perform in Marketing on Social Media Websites? Journal of Travel \& Tourism Marketing, 28(4), 345-368. doi:10.1080/10548408.2011.571571

Chang, Y.-C., Ku, C.-H., \& Chen, C.-H. (2019). Social media analytics: Extracting and visualizing Hilton hotel ratings and reviews from TripAdvisor. International Journal of Information Management, 48, 263279. doi:10.1016/j.ijinfomgt.2017.11.001 
Chen, C., Zhang, D., Guo, B., Ma, X., Pan, G., \& Wu, Z. (2016). TripPlanner: Personalized trip planning leveraging heterogeneous crowdsourced digital footprints. IEEE Transactions on Intelligent Transportation Systems, 16(3), 1259-1273.

Cheng, M., \& Edwards, D. (2015). Social media in tourism: a visual analytic approach. Current Issues in Tourism, 18(11), 1080-1087. doi:10.1080/13683500.2015.1036009

Cholprasertsuk, A., Lawanwisut, C., \& Thongrin, S. (2020). Social Media Influencers and Thai Tourism Industry: Tourists' Behavior, Travel Motivation, and Influencing Factors. Journal of Liberal Arts Thammasat University, 20(2), 234-263.

Chu, S.-C., Deng, T., \& Cheng, H. (2020). The role of social media advertising in hospitality, tourism and travel: a literature review and research agenda. International Journal of Contemporary Hospitality Management, 32(11), 3419-3438. doi:10.1108/IJCHM-05-2020-0480

Cox, C., Burgess, S., Sellitto, C., \& Buultjens, J. (2009). The Role of User-Generated Content in Tourists' Travel Planning Behavior. Journal of Hospitality Marketing \& Management, 18(8), 743-764. doi:10.1080/19368620903235753

Dan, W., Xiang, Z., \& Fesenmaier, D. (2014). Adapting to the Mobile World: A Model of Smartphone Use. Annals of Tourism Research, 48, 11-26. doi:10.1016/j.annals.2014.04.008

Fotis, J., Buhalis, D., \& Rossides, N. (2012). Social media use and impact during the holiday travel planning process. In M. Fuchs, F. Ricci, \& L. Cantoni, Information and communication technologies in tourism (p. 24). Helsingborg, Sweden, Austria: Springer-Verlag Wien. doi:10.1007/978-3-7091-1142-0

Goeldner, C. R., \& Ritchie, J. R. (2011). Tourism: Principles, Practices, Philosophies (12th Edition ed.). Hoboken(New Jersey): John Wiley \& Sons Inc.

Gohil, D. N. (2015). Role and Impact of Social Media in Tourism: A Case Study on the Initiatives of Madhya Pradesh State Tourism. International Journal of Research in Economics and Social Sciences, 5(4), 815.

Gretzel, U., Kang, M., \& Lee, W. (2008). Differences in Consumer-Generated Media Adoption and Use: A Cross-National Perspective. Journal of Hospitality \& Leisure Marketing, 17(1-2), 99-120. doi:10.1080/10507050801978240

Hays, S., Page, S. J., \& Buhalis, D. (2013). Social media as a destination marketing tool: its use by national tourism organisations. Current Issues in Tourism, 16(3), 211-239. doi:10.1080/13683500.2012.662215

Hidayat, A., \& Are, R. L. (2018). The Impact Of Social Media As Promotion Tools Towards Intention To Visit: Case Of Batu, Malang, Indonesia. Advances in Economics, Business and Management Research (AEBMR), 60-71. doi:10.2991/ictgtd-18.2018.9

Huang, Y., Basu, C., \& Hsu, M. K. (2010). Exploring Motivations of Travel Knowledge Sharing on Social Network Sites: An Empirical Investigation of U.S. College Students. Journal of Hospitality Marketing \& Management, 19(7), 717-734. doi:10.1080/19368623.2010.508002

Hudson, S., \& Thal, K. (2013). The Impact of Social Media on the Consumer Decision Process: Implications for Tourism Marketing. Journal of Travel \& Tourism Marketing, 30(1-2), 156-160. doi:10.1080/10548408.2013.751276

Jang, S., \& Park, K. (2011). Hospitality finance research during recent two decades: Subjects, methodologies, and citations. International Journal of Contemporary Hospitality Management, 23(4), 479-497. doi:10.1108/09596111111129995

Jin, L., Long, X., Zhang, K., Lin, Y.-R., \& Joshi, J. (2016). Characterizing users' check-in activities using their scores in a location-based social network. Multimedia Systems, 22, 87-98. doi:10.1007/s00530-0140395-8

John, S., Larke, R., \& Kilgour, M. (2018). Applications of social media for medical tourism marketing: an empirical analysis. Anatolia, 29(4), 553-565. doi:10.1080/13032917.2018.1473261 
Kaplan, A., \& Haenlein, M. (2010). Users of the World, Unite! The Challenges and Opportunities of Social Media. Business Horizons, 53(1), 59-68. doi:10.1016/j.bushor.2009.09.003

Kayumovich, K. O., \& Kamalovna, S. F. (2019). SOCIAL MEDIA-MARKETING - A FORCEFUL TOOL FOR TOURISM INDUSTRY. European science, 7(49), 41-43.

Kennedy, G., Dalgarno, B., Gray, K., Judd, T., Waycott, J., Bennett, S., . . Churchward, A. (2007). The net generation are not big users of Web 2.0 technologies: Preliminary findings. Proceedings ascilite Singapore 2007, (pp. 517-525). Retrieved from https://www.ascilite.org/conferences/singapore07/procs/kennedy.pdf

Királová, A., \& Pavlíčeka, A. (2015). Development of Social Media Strategies in Tourism Destination. Procedia - Social and Behavioral Sciences, 175, 358-366. doi:10.1016/j.sbspro.2015.01.1211

Kurashima, T., Iwata, T., Irie, G., \& Fujimura, K. (2010). Travel route recommendation using geotags in photo sharing sites. CIKM '10: Proceedings of the 19th ACM international conference on Information and knowledge management (pp. 579-588). New York, NY, USA: Association for Computing Machinery.

Leung, D., Law, R., Hoof, H. v., \& Buhalis, D. (2013). Social Media in Tourism and Hospitality: A Literature Review. Journal of Travel \& Tourism Marketing, 30(1-2), 3-22. doi:https://doi.org/10.1080/10548408.2013.750919

Leung, X. Y., Sun, J., \& Bai, B. (2017). Bibliometrics of social media research: A co-citation and co-word analysis. International Journal of Hospitality Management, 66, 35-45. doi:https://doi.org/10.1016/j.ijhm.2017.06.012

Lewis, D., \& Bridger, D. (2001). Soul of the New Consumer: Authenticity - What We Buy and Why in the New Economy. America: Nicholas Brealey.

Litvin, S., Goldsmith, R. E., \& Pan, B. (2008). Electronic Word-of-Mouth in Hospitality and Tourism Management. Tourism Management, 29(3), 458-468. doi:10.1016/j.tourman.2007.05.011

Lo, A. S., \& Yao, S. S. (2019). What makes hotel online reviews credible? An investigation of the roles of reviewer expertise, review rating consistency and review valence. International Journal of Contemporary Hospitality Management, 31(1), 41-60. doi:10.1108/IJCHM-10-2017-0671

Lo, I. S., Mckercher, B., Lo, A. S., Cheung, C., \& Law, R. (2011). Tourism and Online Photography. Tourism Management, 32(4), 725-731. doi:10.1016/j.tourman.2010.06.001

Mariani, M., Styven, M. E., \& Ayeh, J. K. (2019). Using Facebook for travel decision-making: aninternational study of antecedents. International Journal ofContemporary Hospitality Management, 31(2), 1021 1044. doi:10.1108/IJCHM-02-2018-0158

Moro, S., \& Rita, P. (2018). Brand strategies in social media in hospitality and tourism. International Journal of Contemporary Hospitality Management, 30(1), 343-364. doi:10.1108/IJCHM-07-2016-0340

Noone, B., McGuire, K. A., \& Rohlfs, K. V. (2011). Social media meets hotel revenue management: Opportunities, issues and unanswered questions. Journal of Revenue and Pricing Management, 10(4), 293-305.

Roque, V., \& Raposo, R. (2016). Social media as a communication and marketing tool in tourism: an analysis of online activities from international key player DMO. Anatolia, 27(1), 58-70. doi:10.1080/13032917.2015.1083209

Sahoo, D. S., \& B.G, M. M. (2017). Role of Social Media in Promoting Tourism Business - A Study on Tourism Promotion in Odisha. INTERNATIONAL CONFERENCE PEOPLE CONNECT: NETWORKING FOR SUSTAINABLE DEVELOPMENT (pp. 272-281). International Journal of Creative Research Thoughts (IJCRT).

Sharda, N., \& Ponnada, M. (2008). Tourism Blog Visualizer for better tour planning. Journal Of Vacation Marketing, 14(2), 157-167. doi:10.1177/1356766707087523 
Tussyadiah, I., \& Fesenmaier, D. (2009). Mediating Tourist Experiences: Access to Places via Shared Videos. Annals of Tourism Research, 36(1), 24-40. doi:10.1016/j.annals.2008.10.001

Tussyadiah, I., Park, S., \& Fesenmaier, D. (2011). Assessing the Effectiveness of Consumer Narratives for Destination Marketing. Journal of Hospitality and Tourism Research, 35(1), 64-78. doi:10.1177/1096348010384594

Vu, H. Q., Li, G., Law, R., \& Zhang, Y. (2017). Tourist Activity Analysis by Leveraging Mobile Social Media Data. Journal of Travel Research, 57(7), 1-16. doi:10.1177/0047287517722232

Wei, F. (2015). Research on the Internet's Impact on Tourism Distribution Channels in the Era of Smart Tourism. Advances in Intelligent Systems Research, 130, 253-256.

Winduwati, S., \& Putri, C. R. (2020). The Role of Social Media and Youth Participation in Developing Local Tourism (Case Study On Generasi Pesona Indonesia Lombok). Advances in Social Science, Education and Humanities Research, 478, 905-909.

Xiang, Z., \& Gretzel, U. (2010). Role of social media in online travel information search. Tourism Management, 31(2), 179-188. doi:10.1016/j.tourman.2009.02.016

Xiang, Z., Du, Q., Ma, Y., \& Fan, W. (2017). A comparative analysis of major online review platforms: Implications for social media analytics in hospitality and tourism. Tourism Management, 58, 51-65. doi:10.1016/j.tourman.2016.10.001

Xiang, Z., Wang, D., O’Leary, J. T., \& Fesenmaier, D. R. (2014). Adapting to the Internet: Trends in Travelers' Use of the Web for Trip Planning. Journal of Travel Research, 54(4), 511-527. doi:10.1177/0047287514522883

Ye, Q., Law, R., Gu, B., \& Chen, W. (2011). The influence of user-generated content on traveler behavior: An empirical investigation on the effects of e-word-of-mouth to hotel online bookings. Computers in Human Behavior, 27(2), 634-639. doi:10.1016/j.chb.2010.04.014

Zarezadeh, Z. Z., Rastegar, H. R., \& Gretzel, U. (2018). Reviewing the Past to Inform the Future: A Literature Review of Social Media in Tourism. Czech Journal of Tourism, 7(2), 115-131. doi:https://doi.org/10.1515/cjot-2018-0006

Zeng, B., \& Gerritsen, R. (2014). What do we know about social media in tourism? A review. Tourism Management Perspectives, 10, 27-36. doi:10.1016/j.tmp.2014.01.001

Živković, R., Gajic, J., \& Brdar, I. (2014). The Impact of Social Media on Tourism. E-Business in tourism and hospitality industry, 758-761. 